UDC 81'42:004.77

DOI https://doi.org/10.32838/2710-4656/2021.6-2/10

Pashayeva G. B.

Sumgait State University

\title{
TEXT, DISCOURSE AND VIRTUAL DISCOURSE
}

In modern time one of the main topics involved in linguistic research is the concept of text and discourse beside this, the concept of virtual discourse has been recently added to these research topics. Although all three terms are formally similar, research has shown that, in fact, these concepts are separated by the various lines. The main purpose of the research is to define these lines. The presented article analyses the peculiarities of text, discourse and virtual discourse. Thus, with reference to the views of Azerbaijani and foreign linguists, information was provided on all three concepts, and the main features of the connection between them were clarified. Although all three concepts are interrelated, there are some differences between them. The main purpose of the research is to clarify the similarities as well as the differences between these concepts, and as for us we have achieved it partly in this research paper. Thus, the article examines the individual features of each of the concepts of text, discourse, virtual discourse and compares them with each other. Using a comparative method, all three concepts were explored by comparison methods. In the article, we have tried to present our opinion by a reasonable method by presenting special tables. In addition, the main features of virtual discourse, a new concept in the Azerbaijani language, were studied, and its peculiarities were listed. Recently, virtual discourse as the basis of communication has been studied as a fact of language. The article reflects modern times, showing the concept of virtuality in terms that exist in linguistics. At the end of the article, the individual features of the concept of text, discourse and virtual discourse are compared and presented in tabular form. We think that this abstract, which we present as a fact of result, clearly shows the main purpose of the article.

Key words: communication, discourse, virtual reality, virtual discourse, virtual identity.

Formulation of the problem. Communication is a concept necessary for human life, regulated by the specific requirements of society, the main essence of social, cultural and economic relations. It is no coincidence that the speech of primitive people, to communicate with sounds which appear from need, played a main role in their evolutionary process, in their transformation into "Homosapiens". Communication has acted and continues to act as a way to form a person's personality, a necessary condition for the normal development of a person as a member of society, a condition for mental and physical health, a way to get to know other people and himself. "Outside of communication, a person cannot appear as a human being" [1, p. 11].

Due to its great social significance, communication, types, genres and forms of communication still attract the attention of scientists and thus lead to the emergence of new concepts. It can be said with certainty that it is communication forms society and allows a person to become and develop as an individual in society, linking behavior to the actions and behaviors of others. "Communication is the interaction of members of a society in order to determine their relationship with each other and to exchange views" [2, p. 12].
There are different types, genres, forms of communication. Its main types, verbal and nonverbal, written and oral forms of communication, combine several main problems. Thus, these forms, which were once quietly passed over, have today become the object of research, resulting in the emergence of new concepts in linguistics.

Analysis of recent research and publications. One of the new concepts that have recently emerged in linguistics, as well as one that has not been clarified, is the concept of discourse. The etymology of this word dates back to the 14th century and is derived from the Latin word "discurcus", which means to communicate, to talk, to speak. Although the history of the word related long to the past, the study of discourse dates back to the 1960s. Firstly, Z. Harris spoke in his article named "Discourse Analysis", which he understood as a method of sequential speech analysis, which considers the relationship between culture and language in 1952 [3]. The scholar described discourse as a "combination of expressions" that interacts with each other. In his work, he used the concepts of text and discourse as synonyms.

Currently, the term "discourse" is used in different senses in linguistics., because there are different approaches to the definition of discourse - 
formal-structural,

functional-structural, sociolinguistic, critical. Although there is little scientific research in this field in the Azerbaijani language, there are many foreign linguists who try to systematize the study of this phenomenon, taking into account the different definitions of the term, the features of each of the existing approaches, discourse and text concepts.

The study of discourse is at the crossroads of a number of scientific subjects. Semiotics, sociolinguistics, pragmatics, anthropology, communication theory and other related scientific subjects aimed at studying the function of language are related to the study of discourse as an independent interdisciplinary direction. Although actively studied in various aspects of discourse, there is still no unambiguous interpretation of the term "discourse".

In general, when studying research, it becomes clear that it is difficult for linguists to analyze and clarify the concept of discourse as a whole. In almost all theses, a conclusion is reached by comparing the concepts of discourse and text. We think that clarifying the peculiarities of this concept, which we called a text for a long time, is one of the urgent requirements of linguistics today. In defining discourse in the modern linguistic tradition, it is clear that this concept is increasingly different from the concept of text.

It's interesting, what are the features that bring the concepts of text and discourse so close each other? Or what is the need to use the term discourse when there is a concept of text?

In N.V. Cheremisina's “O гармонии композиции художественного целого, Язык и композиция художественного текста" author states that "Discourse is a combination of a sentence and a series of sentences with a coherent internal meaning, ensuring a complete understanding of such a combination" [4, p. 10].

T.M. Nikolaeva's discourse is "1) a coherent text; 2) oral form of the text; 3) dialogue; 4) a group of expressions related to each other in terms of meaning; 5) a given (written or oral) work of speech" [5].

When getting acquainted with the scientific literature in the Azerbaijani language, it becomes clear that the boundaries of these two concepts have not been fully defined yet. Thus, trying to distinguish between discourse and text, F. Veysalli writes:

1. The discourse covers the social-lingual sphere, and the text belongs to the purely linguistic sphere. A text is a verbal representation of a communication event, and a discourse is a text in terms of an event, a conversation loaded with life force, ie a language used in active communication. It is better if the text is applied to the text. In this case, the discourse can be taken as a purely colloquial element. But discourse can be understood in the sense of the application of language.

2. In the encounter of discourse and text, the first is taken as a process and the second as a result of the process. This means that the discourse is an action, an action, connected with a real act of speech. The text is a fixed, complete form.

3. Another attempt to differentiate is the actualvirtual encounter of discourse and text. According to this approach, discourse, like a real conversational event, is a coherent text in a current conversation. The text is related to real time, it is abstract, mental construct, and it is realized in discourse.

4. Discourse is not discrete; it is related to a communicative event. It does not know the start time or end limit.

5. Discourse as a field of communicative practice is considered to be a set of events, a conversational activity that takes place in a certain social space, it reflects a certain social process and takes place within a certain time [6, p. 23].

Based on the above, it can be said that the active language is discourse. That is, discourse is oral speech.

According to the Russian researcher N.A. Kulibina, with a book as a written text, it is possible to define the boundaries of the concept of discourse and text by distinguishing the book read by any person [7].

It turns out that discourse can take place in the text; it does not exist outside the text. So, for the realization of discourse, it is necessary to have a text and context. Due to this feature, it is sometimes identified with the text.

Discourse is a communicative activity. When you look through researchers' articles, it becomes clear that discourse is a communicative activity. This activity takes place only during the active period of linguistic communication. Passively, that is, in writing, this text should be called. According to F. Veysalli, who called discourse a process and text a result, a text can even consist of several discourses, which proves that the text is larger than the discourse. [5] However, we think that the dictation itself may consist of several texts, which tells us that it is still questionable whether the text or the dictation is larger. However, taking into account the wide range of possibilities of modern linguistics - types, possibilities of expression, numerous individual features, it can be said that discourse is a broader concept than the text, it is multifaceted and is constantly evolving and enriching. 
In general, after reviewing the theses, it can be concluded that the discourse itself is divided into certain types. For example, political discourse, academic discourse, socio-political discourse, military discourse, artistic discourses, etc. Each of these discourses has its own characteristics, each of which can be a separate object of study.

As we have noted, discourse is an active form of communication, and based on the fact that it is a motor activity, we must say that discourse does not exist alone. There must be a factor that turns it into a process and engages it in action. That is, the main condition here is the speaker and the listener. In this case, it should be noted that there is a concept of time and space for discourse. This is not the case in the text. Text as a passive form of communication can be intended for any time and place.

What is the similarity between text and discourse?

In modern linguistics, there is still no consensus on the criteria that form the basis of the definition of the text. Most linguists believe that the concept of "text" cannot be defined in a purely linguistic method. Text is, above all, a communicative concept aimed at defining the characteristics of a particular type of activity. The text is functionally understood as a unit of communication, both written and oral. We think that we can clarify the basis of the text with the following features.

1) Integrity. One of the most important features of the text is integrity. Galperin, Nikolaeva, Sorokin, Stern and others llinguists attribute integrity to the semantic (content) side of the text. In traditional linguistics, integrity is considered a purely textual category. In general, the integrity of the text is also considered in psycholinguistics in terms of the perception of the text.

2) Cohesion. The logical basis of the text is provided by cohesion. "Cohesion" means a combination, an approach this concept understands the interconnectedness of the text, the internal connection. Cohesion is the main means of making speech harmonious and understandable.

3) Compatibility. That is, the correct expression of the reality of the selected expressions. According to this principle, such lexical units should be chosen for the expression of the idea that these units should achieve a clear idea of the idea.

When enumerating the individual features of the text, we must not forget that these features are directly related to the discourse, because the discourse itself does not exist outside the text. Discourse is formed and formed on the basis of the text of course these features also apply to the texts that make it up.

We think that the main similarity between these two concepts is that they are both informative. Text and discourse, whether written or oral, are linguistic facts of information and communication. So, the text has only informative and partially communicative function (letter). Based on the fact that the discourse is verbal, we can say that it has communicative, informative, emotional, conative functions. In addition, unlike text, discourse also includes feelings and emotions. Of course, it is possible to express feelings in a certain way through punctuation in written speech. However, we must admit that this is very dull in the face of the feelings transmitted to the other side during the speech.

So, the main thing that unites the text and the discourse is that they serve communicativeness, which is the basis of communication. Thus, the fact of both languages can be considered types of communication. We would like to summarize these features graphically as follows (Table 1).

Changes in society, cultural and economic development also have an impact on language. Of course, it is not certain that this effect always promises good results, but it seems that almost no language can avoid this effect. It is no coincidence that the concept of virtual discourse has entered linguistics along with

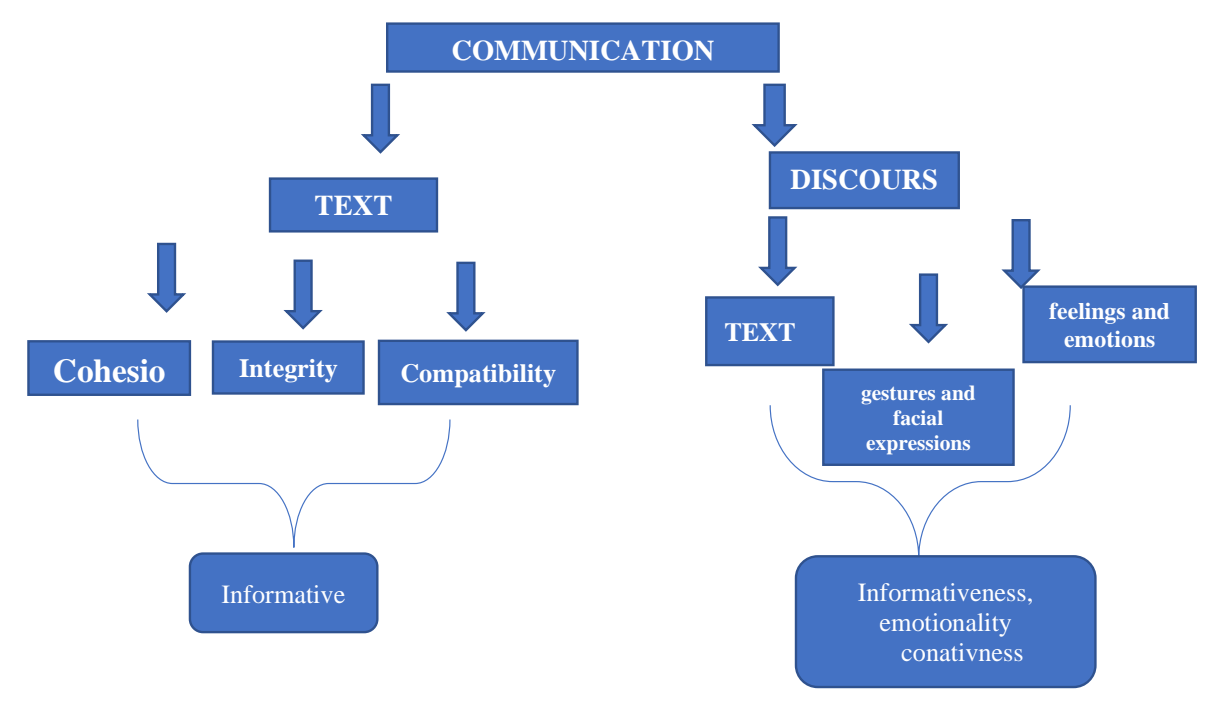

Table 1 
the concept of text and discourse, as the Internet has become a part of our lives. The communication environment created by the development of new information technologies leaves a big mark on all aspects of communication, and as a result we have to come across several terms in this regard. For example, computer chats, electronic discourse, internet discourse, online discourse, virtual discourse, etc. The types of discourse listed, as a distinctive feature, indicate the nature of the interaction that determines a particular means of communication or the communication environment created. Virtual discourse is a text that is a form of communication that takes place in virtual reality and distinguishes it from other types of discourse.

Although the concept of virtually has existed since ancient times, the use of the term "virtual" and its derivatives has recently become very popular due to the rapid development of information technology. For example, virtual culture, virtual world, virtual consciousness, virtual space, virtual reality, virtual market, virtual money, virtual identity, virtual name, and so on.

Before proceeding to the analysis of virtual discourse, which is the object of our research, it is necessary to clarify the concept of virtually or virtual reality. The explanation of the virtual word in the explanatory dictionary of the Azerbaijani language is presented as follows.

1. Fact-based, true reality.

2. Possible, in the frame of opportunity, under certain conditions.

3. Imaginary, non-original [8].

Looking at the above explanations, it can be said that the word virtual is currently used in the Azerbaijani language mainly in the sense of "imaginary, nonoriginal". However, in the concept of virtual discourse, this meaning is not always clear, because virtual discourse can stand in reality. In other words, the virtual word is now able to expand its semantics and create a concept. For example, today, perhaps each of us has a virtual friend or acquaintances that we meet on the Internet. This virtual friend is imaginary, not fictional. It exists and can meet all the features of the concept of friendliness for us. So, in this sense, a new expression is emerging in the language, the concept of virtual reality.

If we try to express the concept of virtual reality or virtual reality in synonyms, we come across different options, and I think that these expressions can convey the exact meaning of the concept presented to us. For example, imaginary reality, artificial reality, subjective reality, temporary reality, created reality, symbolic reality, imitation reality, established reality, and so on. In contrast to these expressions, if we consider the phrases real reality, objective reality, real reality, social reality, material reality, natural reality, permanent reality, real reality, which express objective reality, the essence of virtual reality will be completely clear to us.

The concept of virtually was later used in the context of scholastic philosophy in connection with the theory of possible philosophy. In "The Real World - The Virtual World in the World of Words", A.A. Bragin analyses in detail the etymology of the word "virtual" and its placement in the dictionaries of different languages in one way or another: "This word gradually leaves the real world and has a scholastic, philosophical meaning" [9, p. 45]. The basis of virtual reality is intangible concepts - information, thoughts and images. In addition, virtually, unlike other mental derivatives such as the imagination, is characterized by the fact that man perceives and lives as a given thing, not as a product of his mind.

Based on ideas about virtual reality, it can be said that it is understood in different ways. For example, as an extremely broad concept in which any reality is understood as virtual reality. From this point of view, reality is generally virtual, because the subject interacts not only with the subjective world, but also with thoughts about it.

Psychological virtual reality. In this case, the human mind is an artificial, constructed realimaginary image born in different ways. It is an image that man invents, gives it various images and connects it with certain events. This virtual reality can also be called the virtual reality of cognitive and social models, abstract concepts and categories that do not correspond to real physical processes.

In general, the concept of virtual conversation is not limited to the Internet. Certain analyze show that this is directly related to a person's psychological condition. For example, in the novel "Angel from Hell" presented by kulis.az, the main hero of the work Birja often talks to his imaginary friend, shares his worries and sorrows with him.

"... I did not know myself, you introduced me to myself. You took me out of me and showed me, you made me love myself. You gave me confidence, hope, and courage. I was a widow, a helpless slave; I became an angel in your mighty hands. You exalted me. By the magic of your words, you awakened the sleeping angel in me, and entrusted him with the helm of my life, wandering in this ruthless ocean without a compass. You convinced me that there was a treasure inside me, and you urged me to open this treasure. Suddenly the gates of paradise opened wide 
for me, I set foot in your paradise, my friend. You wanted to convince me that this paradise was not on the sidelines, but inside me, but I still feel in your, in your paradise. I believe in you, my friend, I trusted you, my friend; I prayed for you, I believed in you. In Your Paradise, I fell on my knees and fell into a deep sleep. I wanted to tell you the sad story of my life in a dream of hell. Listen to me, my dear friend, remove the thorns from my soul one by one, put ointment on the wounds of my heart, and do not leave me without you again" [10].

In the text we present above, the hero recalls the virtual friend he created in his dream. There are many such examples in Azerbaijani literature.

Virtual reality in the context of information technology: In this case, virtual reality is considered in close connection with a computer and the Internet. And in this regard, the most effective achievement of new information technologies is not only observation and experience, but also the ability to act in virtual reality. Virtual personalities are formed in virtual reality, and modern man is one of such personalities.

Returning to the relationship between the different types of discourse, it should be noted that the terms "computer conversation" and "electronic discourse" are synonymous and refer to a text that is realized through electronic means of communication.

One of the distinguishing features of modern society is the rapid development of technology, which is mainly reflected in the field of communication, and these forms of communication on the Internet are of particular interest. Today, the Internet is perceived as both an information technology and a kind of communicative, socio-cultural phenomenon. Today, the Internet is a space or an environment of people and their countless interactions. This environment is not just a technology, but a reason to collaborate, participate and care.

Virtual discourse is a very common type of communication on the Internet, it develops according to its own norms, has certain goals, values, strategies, genres. To study virtual discourse, it is enough to observe in a virtual space to determine its main features. These features can be listed as follows.

1. The emergence of virtual discourse gave impetus to the introduction and formation of a group of words called slang in the Azerbaijani language, at the same time, slang is currently used in virtual communication.

2. Virtual discourse was able to transfer the features of oral speech to written speech. Of course, this is not a good indicator for language, but the fact is that in a virtual space, written speech is equated with oral speech. Incomplete sentences, conversions, distorted words, etc.

3. Virtual discourse has created special cues for the written expression of feelings and emotions, which can be used to make people who write online laugh, get angry and sad.

4. Virtual discourse provided the emergence of virtual personalities and virtual names, which created a new direction in the study of anthroponomy.

Interestingly, many concepts that have long been the object of research in linguistics feel the need to be reworked against the background of the concept of virtual reality. For example, slang has long been included in the group of words we have called slang and slang, and we think that their features should be re-examined and their boundaries defined.

Or the well-known features of oral and written speech in the Azerbaijani language, which have maintained their stability for many years, are completely violated during virtual discourse, and new criteria emerge.

It was difficult to convey the feelings and emotions that we conveyed to the other side using facial expressions and gestures in oral speech, but it is not difficult to present it in virtual discourse. I think that these issues can be reflected in the concept of emotion.

Examining the differences between the concepts of text and discourse, it becomes clear that discourse is oral speech. However, this is not clear about virtual discourse. As we have noted, discourse is a moving language, interactive. Communication is active here. In modern times, virtual discourse is carried out by various technical means, and this process is interactive, even if it is in writing. So, discourse is oral speech, but virtual discourse takes place both orally (virtual conferences, virtual lessons, virtual meetings, etc.) and in written form (e-mail, correspondence on social networks; messenger, direct, words-up, telegram, etc.).

As mentioned above, discourse needs a mediator. If there is no mediator, there is no discourse. Based on this, we can say that virtual discourse also requires a mediator, and this requirement "cultivates" a virtual identity. Of course, the expression of virtual identity itself can be an object of research. But in a nutshell you can answer the question of who is a virtual identity. Virtual personalities are people who join the discourse with virtual names and nicknames. These people can be people we know or people we don't know. "The development of information technology in modern times has led to the emergence of new name substitutes. The main means of self- 
Table 2

\begin{tabular}{|l|c|c|c|}
\hline \multicolumn{1}{|c|}{ Features } & Text & Discourse & Virtual Discourse \\
\hline Is oral speech & - & + & + \\
\hline Is written speech & + & - & + \\
\hline Is interative & - & + & + \\
\hline Having communicative function & partly & + & + \\
\hline Having informative function & + & + & + \\
\hline Having emotive function & - & + & + \\
\hline Having conotative function & - & + & partly \\
\hline Literary language norms are preserved & + & partly & + \\
\hline Needs a mediator & - & + & + \\
\hline Needs a listener & - & + & + \\
\hline The concept of time exists & - & + & + \\
\hline It is possible to express feelings and emotions & - & + & + \\
\hline Need intonation, gestures, facial expressions & - & + & + \\
\hline It is possible to express emotions using special symbols & - & - & + \\
\hline
\end{tabular}

presentation on the Internet is nicknames - names used for communication on the Internet. The main issue that arises in connection with their characteristics is the position of the new names in the anthroponomical system. It is more expedient to consider Nicknames as a virtual name / virtual anthroponomy" $[11$, p. 8].

As can be seen, virtual discourse itself gives rise to new terms and concepts, each of which is a key part of the concept of virtually.

Conclusion. Thus, summarizing our ideas, we can say that the concepts of text, discourse, virtual discourse are closely related to each other, but each has its own characteristics, which can be the subject of separate research. On the other hand, we think that there is a need to study more deeply and clearly define the boundaries between them. As a result of the research, we have tried to summarize the similarities and differences between the text, discourse, and virtual discourse in the table below (Table 2).

Scientific novelty. Although the concept of text and discourse has recently been involved in scientific research, the connection, differences and commonalities between virtual discourse and this trio are being studied for the first time in the Azerbaijani language. This article analyzes and compares the peculiarities of text, discourse and virtual discourse.

\section{References:}

1. Eminli B.İ., Paşayeva G.B. Azərbaycan dilində işgüzar və akademik kommunikasiya. Sumqayıt, 2021. 400 s.

2. Eminli B.I. Qeyri-verbal ünsiyyətin etnokulturoloji səciyyəsi. Sumqaylt Dövlat Universiteti. Elmi xəbərlar. Sosial va Humanitar elmlar bölmasi. 2021. № 1. S. 10-15. URL: https://www.ssu-scientificnews.edu.az/pdf/ S21-1.pdf.

3. Harris Z. Discourse analysis: A small text. Language, NY : Linguistic Society of America. 1952. Vol. 28. № 4. P. 1-30.

4. Черемисина Н.В. О гармонии композиции художественного целого. Язык и композиция художественного текста. Москва, 1983.

5. Николаева Т.П. Инновационный характер экономической структуры в постиндустриальном обществе. Инновачии. 2001. № 9-10. С. 38.

6. Veysəlli F.Y. Diskurs təhlilinə giriş. Bak1 : Təhsil, 2010. 140 s. URL: http://web2.anl.az:81/read/page. php?bibid=152837\&pno $=12$.

7. Кулибина Н.В. Художественный дискурс как актуализация художественного текста в сознании читателя. Мир русского слова. 2001. № 1.

8. Explanatory dictionary of the Azerbaijani language (in 4 volumes) / ed. A. Orujov, B. Abdullayev, N. Rahimzade. Baku : East-West, 2006. 712 s. URL: https://www.ebooks.az/view/7yRJ3CIc.pdf.

9. Брагина А.А. Мир реальный - мир виртуальный в мире слов. Словарь и культура русской речи: К 100-летию со дня рождения С.И. Ожегова. Москва : Индрик, 2001. С. 44-58.

10. Birja. My mother wanted to kill me (excerpt from the novel). 2016. November 17. URL: https://kulis.az/news/16553. 
11. Həbibli R.Y. Virtual məkanda nikneymlərin işlənmə xüsusiyyətləri. Sumqayıt Dövlət Universiteti. Elmi xabarlar. Sosial va Humanitar elmlar bölmasi. 2021. № 1. S. 8-10. URL: https://www.ssu-scientificnews.edu.az/ pdf/S21-1.pdf s.8.

\section{Пашаєва Г. Б. ТЕКСТ, ДИСКУРС І ВІРТУАЛЬНИЙ ДИСКУРС}

Сьогодні однією з основних тем лінгвістичних досліджень є конщепт тексту й дискурсу. Крім иьього, до ичих тем недавно додано поняття віртуального дискурсу. Хоча всі три терміни формально схожі, дослідження показали, що иі поняття насправді розділені різними кордонами. Основна мета дослідження - визначити иі межі. У статті аналізуються особливості тексту, дискурсу та віртуального дискурсу. 3 посиланням на погляди азербайджанських і зарубіжних лінгвістів надано інформацію щодо всіх трьох концепцій, а також з'ясовано особливості зв'язку між ними. Хоча всі три поняття взаємопов'язані, з-поміж них є деякі відмінності. Основна мета дослідження - прояснити подібності, а також різницю між иими кониепиіями, і ми частково досягли цььго в дослідницькій роботі. У статті досліджуються індивідуальні особливості кожного з понять тексту, дискурсу, віртуального дискурсу та порівнюються між собою. Використовуючи порівняльний метод, усі три концепиіїдослідили методами порівняння. Подано спеціальнітаблиці. Вивчено основніриси віртуального дискурсу, нового поняття в азербайджанській мові, перераховано його особливості. Останнім часом віртуальний дискурс як основа комунікаиії вивчається як факт мови. Стаття відображає сучасні уявлення про проблему, показуючи поняття віртуальності в термінах, щцо в лінгвістиці. Наприкінці статті порівнюються індивідуальні особливості концепту тексту, дискурсу та віртуального дискурсу, які представлені в табличній формі.

Ключові слова: комунікачія, дискурс, віртуальна реальність, віртуальний дискурс, віртуальна ідентичність. 